\section{Unstable money}

The turmoil in the foreign exchange markets calls for more durable remedies than now exist.

THE continuing instability of the international currency markets seems to have taken even the world's financial institutions by surprise. Over the past three years, there have been regular meetings of the chief central banks at which the participants have smugly reaffirmed their determination to keep exchange rates stable and their confidence that they could do so. But during the past nine months, the US dollar has been riding a kind of switchback, first falling as people with cash to invest in other people's currencies took fright at the prospect that the US federal deficit would persist, and then rising, like water running uphill, as the same people found encouragement in signs that the remarkably flexible economy of the United States might keep on growing (which is the only remedy for the federal deficit that the Bush administration offers). But now, in the past few days, the dollar has started falling again as the first signs of recession make their appearance. What is going wrong?

The dismal science of economics may on this occasion surely be looked to for an explanation. The world's central banks have been seeking to play a confidence trick on the international community of those who invest in other people's currencies, mostly commercial banks and other financial institutions. By saying they will and can keep exchange rates constant, the central banks have been trying to persuade people that there are no prizes to be won by betting that particular currencies would rise or fall. If people had believed them, their assertion would have come true. In a vacuum, so to speak, the trick might have worked. In the real world, it has not.

Nobody should be surprised. Central banks have only one durable means of affecting the value of their own currency - the rate of interest they require their own commercial banks to pay for money borrowed. Higher interest rates will sustain the value of a currency, lower interest rates work the other way. But the same interest rates affect the real economy. In the long run, they depress economic activity. In poor Britain, the Bank of England's rate has already reached 15 per cent, and may yet go higher, for the British have to persuade other people to hold sterling by compensating them not merely for tying up their money but for the rate at which the value of their assets will be eroded by inflation, now eight per cent (in Britain). In the United States, where inflation runs at a lower rate, lower interest rates still threaten to bring on recession (which is why the US dollar is now falling). The most likely consequence of the banks' confidence trick will be a general recession next year.

Might there have been a better way? The pressure on the foreign exchanges is a measure of the imbalance in world trade. The yen the Japanese earn by their ingenuity do not simply stay in the pockets of their manufacturers but are mostly converted into other currencies by the Japanese commercial banks. After many years of trade imbalance, these sums of money are much greater than can be converted into long-term assets by their owners, which explains why short-term interest rates are now higher than long-term rates - and the foreign exchange markets are uncomfortably volatile as a result. So the central banks should be working harder than they are at increasing long-term interest rates even if that implies that debtor nations as the United States and Britain would be more painfully punished for profligacy.

\section{China in trouble}

The past month's turmoil in China may eventually benefit Chinese science, but the outlook is not cheerful.

CHINA is once more in upheaval. The economic reforms of the past decade, now themselves in hazard, have chiefly affected the peasant farmers able to sell what they produce on a relatively free market and the small urban entrepreneurs who have been allowed to recreate some part of traditional Chinese small business. But university teachers and the army of workers in China's research institutes have been almost untouched by the unwinding of the Cultural Revolution. It is still the norm that people are paid miserable salaries and are expected not to complain too bitterly on the grounds that their housing is almost literally free and, by the same token, is a means by which they are kept captive. There has been some progress in persuading technical people that they might be happier and more productive working more closely with industrial enterprises, but most of the over-large research institutes are still too encumbered with dead wood and ideology. It is not surprising that the promise that China's science would contribute both to the enrichment of China and to general understanding has not materialized.

What will happen now that the academic community's students have taken the lead in a peaceful protest against lack of liberty, and when some of its members are being punished for their effrontery? It is natural that university students should have been in the van of the recent protests; they after all, have the most to lose from a continuation of the sloth that has overtaken the once-reforming leadership in Beijing. It seems unlikely that China's researchers will have much to gain from what happens in the months ahead. But the privations of daily life in China breed fortitude, while the still-fresh legend of the Cultural Revolution is not just a tale of repression, but also a rich anthology of tales of individual heroism and ingenious defiance. That should help keep some people's spirits up. It is also relevant that the weakness that has sapped the resolution and imagination of the Beijing regime is intrinsically self-limiting: even in China, octogenarians cannot hope to live forever. Meanwhile, it is essential that the links with Chinese science forged in the past decade should be kept intact, even strengthened.

NATURE - VOL $339 \cdot 8$ JUNE 1989 